Article

\title{
Inorganic Nitrogen Production and Removal along the Sediment Gradient of a Stormwater Infiltration Basin
}

\author{
Qianyao Si ${ }^{1,+, \ddagger}$, Mary G. Lusk ${ }^{1, *}$ and Patrick W. Inglett ${ }^{2}$ \\ 1 Soil and Water Sciences Department, Gulf Coast Research and Education Center, University of Florida, \\ Wimauma, FL 33598, USA; qianyaosi@ufl.edu \\ 2 Wetland Biogeochemistry Laboratory, Soil and Water Sciences Department, University of Florida, Gainesville, \\ FL 32611, USA; pinglett@ufl.edu \\ * Correspondence: mary.lusk@ufl.edu \\ + Current address: Environmental Science and Technology Department, University of Maryland, College Park, \\ MD 20742, USA. \\ $\ddagger \quad$ Former Member of University of Florida.
}

check for

updates

Citation: Si, Q.; Lusk, M.G; Inglett, P.W Inorganic Nitrogen Production and Removal along the Sediment Gradient of a Stormwater Infiltration Basin. Water 2021, 13, 320.

https://doi.org/10.3390/w13030320

Academic Editor: Peter Weiss

Received: 21 December 2020

Accepted: 21 January 2021

Published: 28 January 2021

Publisher's Note: MDPI stays neutral with regard to jurisdictional claims in published maps and institutional affiliations.

Copyright: (c) 2021 by the authors. Licensee MDPI, Basel, Switzerland. This article is an open access article distributed under the terms and conditions of the Creative Commons Attribution (CC BY) license (https:// creativecommons.org/licenses/by/ $4.0 /)$.

\begin{abstract}
Stormwater infiltration basins (SIBs) are vegetated depressions that collect stormwater and allow it to infiltrate to underlying groundwater. Their pollutant removal efficiency is affected by the properties of the soils in which they are constructed. We assessed the soil nitrogen $(\mathrm{N})$ cycle processes that produce and remove inorganic $\mathrm{N}$ in two urban SIBs, with the goal of further understanding the mechanisms that control $\mathrm{N}$ removal efficiency. We measured net $\mathrm{N}$ mineralization, nitrification, and potential denitrification in wet and dry seasons along a sedimentation gradient in two SIBs in the subtropical Tampa, Florida urban area. Net $\mathrm{N}$ mineralization was higher in the wet season than in the dry season; however, nitrification was higher in the dry season, providing a pool of highly mobile nitrate that would be susceptible to leaching during periodic dry season storms or with the onset of the following wet season. Denitrification decreased along the sediment gradient from the runoff inlet zone (up to $5.2 \mu \mathrm{g} \mathrm{N} / \mathrm{g} \mathrm{h}$ ) to the outermost zone (up to $3.5 \mu \mathrm{g} \mathrm{N} / \mathrm{g}$ h), providing significant spatial variation in inorganic $\mathrm{N}$ removal for the SIBs. Sediment accumulating around the inflow areas likely provided a carbon source, as well as maintained stable anaerobic conditions, which would enhance $\mathrm{N}$ removal.
\end{abstract}

Keywords: stormwater infiltration basins; nitrogen; urban runoff; stormwater best management practices

\section{Introduction}

The effects of stormwater runoff on receiving waterbodies have attracted more attention as urban expansion and development increase globally and as impervious surfaces have taken the place of watershed vegetation and soils. As stormwater runoff washes over impervious surfaces, it can cause flooding and erosion, as well as mobilize and transport various pollutants (e.g., nutrients, metals, and pathogens) that diminish the quality of downstream waterbodies [1-3]. The nutrient loads of stormwater runoff can be especially problematic since excess nitrogen $(\mathrm{N})$ and phosphorus $(\mathrm{P})$ loading to aquatic ecosystems can cause eutrophication and algal proliferation in surface waters and has detrimental effects in groundwater and groundwater-fed ecosystems such as natural springs [4-6]. Sources of $\mathrm{N}$ and $\mathrm{P}$ in stormwater include atmospheric deposition on impervious roads and buildings, leaking or poorly sited septic tanks, sanitary sewer systems, fertilizer residue in lawns and other urban green spaces, leaf litter and grass clippings, and pet waste [7-11].

Stormwater infiltration basins (SIB) are one of the best management practices (BMPs) for controlling both stormwater volumes and stormwater pollutant loads [12,13]. They are designed as dry, excavated basins that hold and release the stormwater runoff through infiltration to underlying soils over a short time period (several days) [12]. The vegetation 
on the basin bottom and sides may maintain and improve infiltration and remove soluble nutrients by biological uptake, as well as help to slow the rate of runoff from the surrounding area, collecting and trapping sediment from stormwater [14]. Both vegetation and soil in SIBs play a role in $\mathrm{N}$ removal through plant uptake, denitrification, and adsorption of ammonium $\left(\mathrm{NH}_{4}{ }^{+}\right)$, although the overall removal efficiencies of total $\mathrm{N}$ are highly variable for SIBs, ranging from negative to $100 \%$ [15]. The majority of removal efficiencies of $\mathrm{N}$, however, are in the 20 to $50 \%$ range for SIBs $[3,13,15]$.

The variability in $\mathrm{N}$ treatment among SIBs comes from a number of environmental factors, including storm events that produce alternating dry and wet soil conditions in the basins [16]. On the one hand, the basins' sediment surfaces can be flooded by the rapid accumulation of stormwater runoff when a rainfall event occurs. On the other hand, the water seeps into the soil in a short time (several days) such that the basin soils become dry again between storm events. In natural systems, such drying-rewetting cycles create fluctuations between an aerobic and an anaerobic environment [17] and have great impacts on $\mathrm{N}$ dynamics in soil, including $\mathrm{N}$ mineralization, microbial biomass, denitrification, and ammonia volatilization $[18,19]$. From the research, we know that in most cases, microbial biomass decreases during dry periods but is stimulated after rewetting [20]. Such dryrewetting phenomenon often makes for a higher net $\mathrm{N}$ mineralization as compared with continuously moist soils [21]. Concomitantly, owing to the restricted diffusion of ions in water films and limited uptake and utilization by plants and microbes, inorganic $\mathrm{N}$ often accumulates in dry soil systems [22]. Upon rewetting after storm events, flooded soil, however, could provide sediments with oxygen-limited conditions and carbon-rich organic matter to conduct denitrification and/or plant uptake, such that inorganic $\mathrm{N}$ is lost from the soil [23,24].

Denitrification is the crucial factor for permanent $\mathrm{N}$ removal in natural and engineered systems, but a carbon source and low oxygen conditions are required in this process [25]. Fluctuating oxygen conditions both between rainfall events and among different SIBs, result from drying and rewetting of sediments and produce temporal and spatial variability in denitrification for SIBs [26]. Denitrification is low in SIBs when incoming nitrate $\left(\mathrm{NO}_{3}{ }^{-}\right)$in runoff has limited opportunities to interact with anaerobic soil zones. In the Morse et al. study [26], while $58 \%$ of incoming inorganic $\mathrm{N}$ was denitrified in a stormwater basin when standing water was present, only $1 \%$ of incoming dissolved inorganic $\mathrm{N}$ was denitrified when there was rarely standing water after rainfall entered the basins [27]. While only a few studies have looked at denitrification in SIBs [27-29], we know from studies of natural systems (that also have periodic flooding such as coastal marshes) that shallow sediments periodically inundated by tidal water could enhance the occurrence of anoxic conditions needed for denitrification [30]. Within a constructed wetland, the denitrification potential was higher at the inlet trough than at mid and outlet locations [31]. This difference in denitrification was attributed to the fact that the inlet trough experienced the highest concentrations of $\mathrm{NO}_{3}$ as compared with other locations in the constructed wetland. The prolonged flooding time was found to be a catalyst to enhance denitrification in a wetland study [32].

A second environmental factor that may affect the efficacy of SIBs for $\mathrm{N}$ treatment is the accumulation of organic matter that likely occurs as the basins receive sedimentladen runoff. The gradual influx of suspended matter in runoff could fill the soil pores, which leads to pore blockage and a reduction of the basins' infiltration treatment capacity. However, as mentioned above, it could alternatively improve the basins' $\mathrm{N}$ removal through denitrification because of the associated addition of carbon necessary for denitrification [33-35]. Several studies have observed a spatial gradient of organic-rich sediments in SIB soils from the inlet pipe to the other end of the basin [36,37], creating a sedimentation gradient along the basins' flow paths. In natural systems, the potential denitrification ability is often positively correlated with the organic matter content in soil [26], because the accumulation of organic matter facilitates the formation of carbon-rich and anaerobic soil zones that increase denitrification [32]. However, the decomposition of soil organic 
matter also releases nutrients, including dissolved inorganic $\mathrm{N}$ into soil [38,39]. Thus, the expected sedimentation gradient in SIBs likely gives rise to spatial variability in the basins' $\mathrm{N}$ treatment potential, but little work has been done to assess the impact of changes in organic matter accumulation and water infiltration on $\mathrm{N}$ transformations and treatment in the infiltration basins.

To gain a better understanding of the roles that wet versus dry seasons and a hydrologic sediment gradient in SIBs play in a variable $\mathrm{N}$ cycling process and a potential inorganic $\mathrm{N}$ transport to the underlying groundwater, in this paper, basic sediment properties and $\mathrm{N}$ cycling process rates were analyzed including potential net mineralization, nitrification, and denitrification rates in an urban subtropical SIB. The purpose of this research is to elucidate soil processes that may influence $\mathrm{N}$ cycling within SIBs in a Florida urban residential setting, with the following research questions: (1) How do soil N cycling processes vary during the summer rainy season and winter dry season? and (2) How will $\mathrm{N}$ removal efficacy via denitrification vary spatially in the sediments of urban stormwater infiltration basins? To the best of our knowledge, our work is the first to investigate temporal and spatial gradients in $\mathrm{N}$ treatment for SIBs, with specific attention to sediment gradients that arise from the flow path of water entering the basins.

\section{Materials and Methods}

\subsection{Site Description}

Soil and water samples were collected from two SIBs located in the Oak Grove neighborhood, a medium-density residential community in Lutz $\left(28^{\circ} 9^{\prime} \mathrm{N}, 82^{\circ} 27^{\prime} \mathrm{W}\right.$, part of the Tampa metropolitan area), Florida, USA, between April 2019 and January 2020 (Figure 1). This region is characterized by a humid subtropical climate with annual average precipitation of $130 \mathrm{~cm}$. The area has a hot and wet season from May to October and a mild and dry season from November through April. The wet season accounts for nearly two thirds of the precipitation during the year on an average basis. The basins are underlain by natural predevelopment soils, which are of the Narcoossee and Panoma series, both of which are deep, sandy Spodosols [40]. The predominant vegetation of both basins is Bahiagrass (Paspalum notatum), a deep-rooted perennial turfgrass which is native to South America and productive on drought prone, sandy soil with low fertility. Each basin (hereafter referred to as SIB 1 or SIB 2) was designed as a grassed basin with one inflow pipe and runoff from the surrounding impervious surfaces directed into the basins via the inflow pipes, which were $0.9 \mathrm{~m}$ diameter concrete pipes.

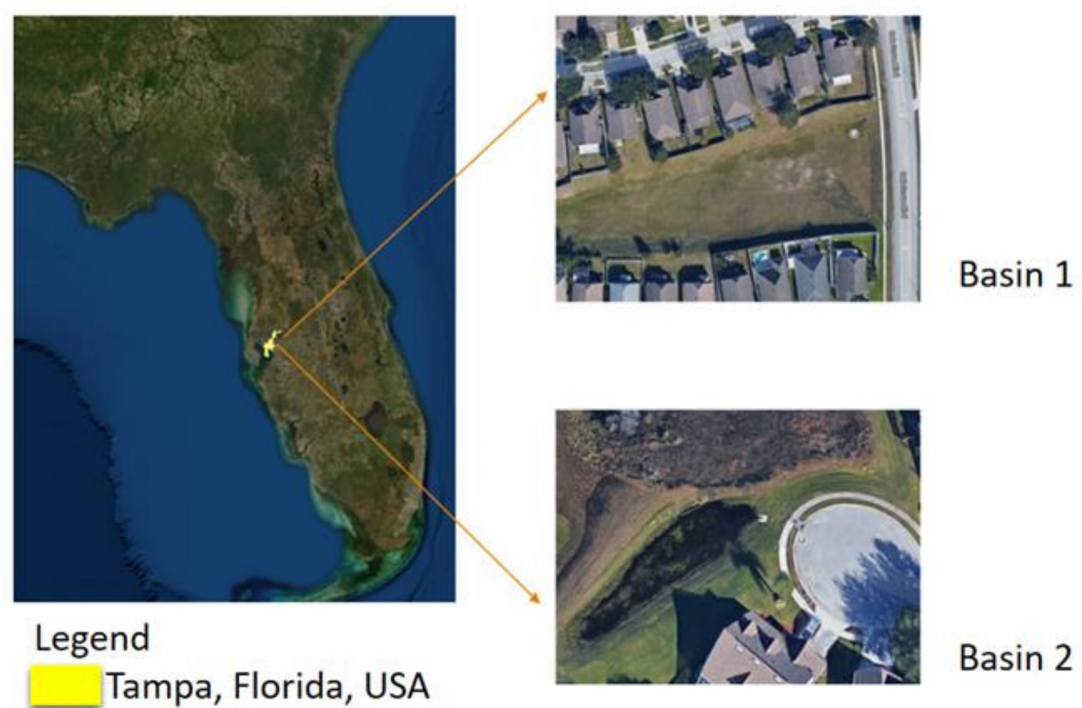

Figure 1. Map of the research site and aerial image of the research stormwater infiltration basins (SIBs) in Lutz, Florida, USA (part of the Tampa FL metropolitan area). 


\subsection{Soil Sampling}

Soils from each SIB were sampled once in each dry season (March 2019) and wet season (August 2019). To investigate the effect of the sediment gradient from the basins' inflow pipes outward, soil samples were collected at the distances of 5, 13, and $21 \mathrm{~m}$ from the inlet pipe within each basin (Figure 2), under the premise that sediment loads from inflowing runoff would accumulate most near the inflow pipe and be deposited to a lesser extent moving outward from the pipe. Zones 1, 2, and 3, in Figure 2, represent areas of frequent flooding, occasional flooding, and rare flooding, respectively. Within each of these zones, three soil replicates were sampled at three depths $(0-30,30-60$, and $60-90 \mathrm{~cm})$ in SIB 1 and two depths (0-30 and 30-60 cm ) in SIB 2 since the seasonal high-water table was reached at the depth of $60 \mathrm{~cm}$ in SIB 2. Replicate soil samples for each distance and depth were composited by mixing in the field and returned to the lab in plastic bags and stored in a cooler. Within $24 \mathrm{~h}$ after sampling, the soil was sieved through a \#10 sieve and stored at $4{ }^{\circ} \mathrm{C}$ until analysis for basic soil physiochemical properties, inorganic $\mathrm{N}$ production, and denitrification rates.

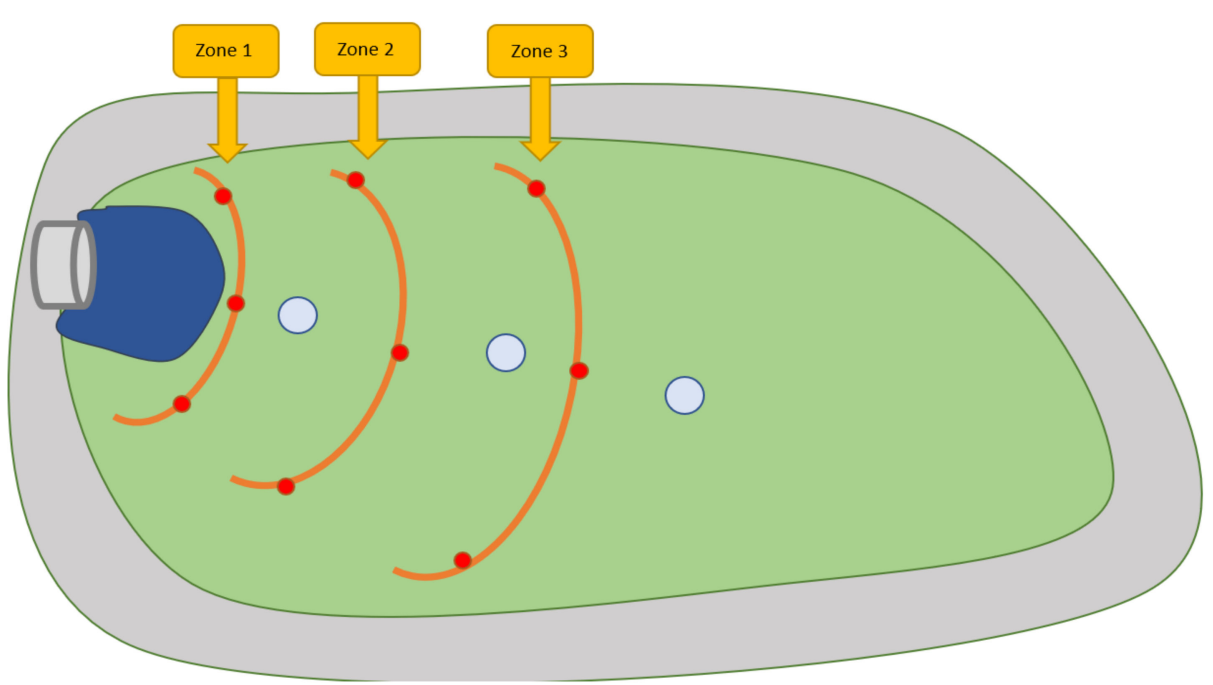

Figure 2. Diagram showing soil sampling point (red dots) and water sampling well (gray circles) distribution in zones of SIB sites. Zone 1 is the frequently flooded zone with hypothesized higher sediment accumulation than the other zones. Zone 2 is occasionally flooded and Zone 3 is rarely flooded.

\subsection{Soil Physicochemical Properties}

We measured soil moisture content by subtracting the weight of soil after oven-drying for $24 \mathrm{~h}$ at $105^{\circ} \mathrm{C}$ from the original weight of wet soils. The soil organic matter content was determined by the loss-on-ignition (LOI) method, which required a $4 \mathrm{~h}$ soil combustion in a muffle furnace at $550{ }^{\circ} \mathrm{C}$. The soil $\mathrm{pH}$ was measured in a 1:2 (soil/water) suspension after settling for 20 min with a Thermo Scientific Advanced Electrochemistry Meter. Soil total $\mathrm{N}$ and total $\mathrm{C}$ were measured at the Wetland Biogeochemistry Laboratory, University of Florida with an elemental analyzer (Thermo Flash EA 1112, CE Elantech Inc., Lakewood, NJ, USA). Soil inorganic $\mathrm{C}$ was determined by measuring the $\mathrm{CO}_{2}$ pressure after mixing soil samples and with ferrous chloride solution and the results were compared with $\mathrm{CaCO}_{3}$ standards from the Wetland Biogeochemistry Laboratory at the University of Florida [41]. Particle size analysis of soils was conducted via the hydrometer method.

\subsection{Biogeochemical Analyses of Soils}

For extractable inorganic $\mathrm{N}$ of SIB soils, $10 \mathrm{~g}$ wet soil samples were extracted by $50 \mathrm{~mL}$ $2 \mathrm{M} \mathrm{KCl}$ solution, with agitation for $1 \mathrm{~h}$ at $90 \mathrm{rpm}$ on a Boekel Flask Dancer. Then, the 
extracts were filtered through \#42 Whatman filter paper and analyzed for $\mathrm{NO}_{\mathrm{x}}-\mathrm{N}$ and $\mathrm{NH}_{3}-\mathrm{N}$ with a continuous segmented flow analyzer (Seal Analytical, Mequon, WI, USA).

For net mineralization and nitrification, we carried out a 14-day soil incubation experiment following the methods of Groffman and Crawford, 2003 [42]. Briefly, $10 \mathrm{~g}$ wet soil was weighed into flasks that were covered by a layer of paper in order to keep air circulating while minimizing moisture loss. At the end of the 14 days, samples were extracted with $2 \mathrm{M} \mathrm{KCl}$ solution and extracts were analyzed for inorganic $\mathrm{N}$ fractions, as described above. Net mineralization rates were determined by comparing the difference between the sum of inorganic $\mathrm{N}\left(\mathrm{NH}_{4}-\mathrm{N}\right.$ and $\left.\mathrm{NO}_{3}-\mathrm{N}\right)$ contents before and after lab aerobic incubation. Nitrification rates were obtained by calculating the difference between $\mathrm{NO}_{3}-\mathrm{N}$ concentrations before and after the incubation.

Denitrification was assessed via the denitrification enzyme activity (DEA) method, utilizing the acetylene inhibition method to determine $\mathrm{N}_{2} \mathrm{O}$ production [43]. Soil samples $(10 \mathrm{~g})$ were amended with $10 \mathrm{~mL}$ DEA solution composed of $0.202 \mathrm{~g} / \mathrm{L} \mathrm{KNO}_{3}, 0.25 \mathrm{~g} / \mathrm{L}$ chloramphenicol, and $0.360 \mathrm{~g} / \mathrm{L}$ glucose and were sealed with rubber septa stoppers in $60 \mathrm{~mL}$ serum bottles. Then, $\mathrm{N}_{2}$ gas was introduced into the serum bottles to remove oxygen inside and to produce anoxic conditions. Approximately $10 \%$ headspace was replaced with acetylene gas to block $\mathrm{N}_{2} \mathrm{O}$ production to $\mathrm{N}_{2}$. Samples were, then, incubated at room temperature $\left(22 \pm 1{ }^{\circ} \mathrm{C}\right)$ in the dark with gentle shaking $(110 \mathrm{rpm})$ for two hours. The concentration of headspace $\mathrm{N}_{2} \mathrm{O}$ was sampled every 30 min and measured using a Shimadzu gas chromatograph (GC-14A, Hewlett Packard) with an electron capture detector. The result was reported as $\mathrm{N}_{2} \mathrm{O}-\mathrm{N}$ produced per gram of dry weight soil per hour, combining the $\mathrm{N}_{2} \mathrm{O}$ gas in air and liquid phases using Bunsen coefficient $\left(0.544\right.$ at $25^{\circ} \mathrm{C}$, $1 \mathrm{~atm}$ pressure).

\subsection{Statistical Analyses}

Data analysis was performed using RStudio software. A 95\% confidence level $(\alpha=0.05)$ was selected for all statistical analysis. Two-way analysis of variance (ANOVA) was conducted to test for differences among wet-dry season, the distance from inflow pipe (horizontal sediment gradient), soil depth, and their interactions on individual response variables, including potential denitrification rate, net mineralization, and nitrification rate. Since ANOVA had revealed significant differences among the results, a Tukey's honestly significant difference (HSD) test was performed as a post hoc test. The relationship between various soil basic variables was evaluated by correlation and regression analysis. A correlation matrix chart was made in order to investigate and visualize the dependence between multiple variables, including potential denitrification rate, mineralization, and nitrification rate with SIB soil features.

\section{Results and Discussion}

\subsection{Soil Physiochemical Properties}

Basic soil physicochemical properties are shown in Table 1. There is a negative correlation between soil $\mathrm{pH}$ values in both basins and increasing distance from the inlet pipes, likely due to increased inorganic $C$ being deposited from incoming runoff near the basins' inlets, which likely comes from concrete materials such as sidewalks and stormwater pipes that convey stormwater runoff [44]. Soil organic matter contents in both basins ranged from 1 to $4 \%$, with soil TOC ranging from 1 to $10 \mathrm{~g} / \mathrm{kg}$. Soil C/N and organic matter content decreased moving from inlet to outlet and with depth at each sampling point. All soils had a sandy texture, except for the first layer of soil around the inlet pipe area in SIB 2, which was sandy clay. While the soil exchangeable $\mathrm{NH}_{4}-\mathrm{N}$ was highly variable and ranged from 1 to $14 \mathrm{mg} / \mathrm{kg}$, extractable $\mathrm{NO}_{3}-\mathrm{N}$ concentrations in soil samples were generally below $1 \mathrm{mg} / \mathrm{kg}$ (Table 2). 
Table 1. Mean SIB soil properties ( \pm standard error) at the $0-30 \mathrm{~cm}$ depth in the wet and dry season and in the 3 sediment zones. Zone 1, frequently flooded; Zone 2, occasionally flooded; Zone 3, rarely flooded.

\begin{tabular}{|c|c|c|c|c|c|c|c|c|c|}
\hline $\begin{array}{c}\text { Location } \\
\text { and Season }\end{array}$ & Zone & $\begin{array}{c}\text { Gravimetric } \\
\text { Moisture (\%) }\end{array}$ & $\begin{array}{c}\text { Organic } \\
\text { Matter (g/kg) }\end{array}$ & Texture & $\mathrm{pH}$ & $\begin{array}{c}\text { Inorganic } \\
\mathrm{C}, \mathrm{g} / \mathrm{kg}\end{array}$ & $\begin{array}{l}\text { Total C } \\
\text { (g/kg) }\end{array}$ & $\begin{array}{c}\text { Total N } \\
\text { (g/kg) }\end{array}$ & $C: N$ \\
\hline \multirow{3}{*}{$\begin{array}{l}\text { SIB 1-wet } \\
\text { season }\end{array}$} & 1 & $21.6(1.5)$ & $34(24)$ & Sand & $8.0(0.4)$ & $0.69(1.03)$ & $2.8(3.8)$ & $0.2(0.1)$ & $8.4(8.2)$ \\
\hline & 2 & 21.5 (1.6) & $33(25)$ & Sand & $6.4(0.2)$ & $0.02(0.03)$ & $1.2(1.4)$ & $0.2(0.1)$ & $4.6(3.5)$ \\
\hline & 3 & $18.3(11.0)$ & $28(23)$ & Sand & $6.4(0.2)$ & $0.04(0.04)$ & $0.9(0.8)$ & $0.2(0.1)$ & $4.4(2.5)$ \\
\hline \multirow{3}{*}{$\begin{array}{l}\text { SIB 1-dry } \\
\text { season }\end{array}$} & 1 & $0.8(0.4)$ & $21(3)$ & Sand & $8.6(0.2)$ & $1.25(0.61)$ & $4.8(2.1)$ & $0.3(0.1)$ & $13.3(3.2)$ \\
\hline & 2 & $1.7(0.9)$ & $16(6)$ & Sand & $7.5(0.7)$ & $0.18(0.04)$ & $1.0(0.7)$ & $0.2(0.1)$ & $4.6(2.6)$ \\
\hline & 3 & $3.2(2.2)$ & $11(5)$ & Sand & $6.4(0.3)$ & $0.17(0.02)$ & $0.4(0.5)$ & $0.2(0.1)$ & $2.1(2.2)$ \\
\hline \multirow{3}{*}{$\begin{array}{l}\text { SIB 2-wet } \\
\text { season }\end{array}$} & 1 & $20.4(1.3)$ & $24(5)$ & Sandy clay & $7.5(0.9)$ & $0.18(0.17)$ & 3.7 (1.9) & $0.4(0.1)$ & $8.6(2.6)$ \\
\hline & 2 & $21.9(2.1)$ & $24(4)$ & Sand & $5.9(0.4)$ & $0.09(0.05)$ & $4.4(1.0)$ & $0.4(0.1)$ & $11.1(2.8)$ \\
\hline & 3 & $19.5(3.9)$ & $22(73)$ & Sand & $6.0(0.7)$ & $0.04(0.02)$ & $4.8(20.4)$ & $0.4(0.1)$ & $12.7(2.8)$ \\
\hline \multirow{3}{*}{$\begin{array}{l}\text { SIB 2-dry } \\
\text { season }\end{array}$} & 1 & $24.3(4.1)$ & $116(71)$ & Sandy clay & $8.6(0.8)$ & $1.82(1.23)$ & $25.1(21.1)$ & 2.2 91.7) & $9.7(3.4)$ \\
\hline & 2 & $18.7(2.9)$ & $38(29)$ & Sand & $6.4(0.4)$ & $0.35(0.20)$ & $1.9(1.7)$ & $0.3(0.1)$ & $5.6(2.5)$ \\
\hline & 3 & $15.2(3.8)$ & 37 (27) & Sand & $6.2(0.9)$ & $0.31(0.28)$ & $2.0(6.2)$ & $0.4(0.3)$ & $5.1(6.0)$ \\
\hline
\end{tabular}

Table 2. Mean exchangeable inorganic N pools ( \pm standard error) in SIB soils at the $0-30 \mathrm{~cm}$ depth in the wet and dry season and in the 3 sediment zones (Zone 1, frequently flooded; Zone 2, occasionally flooded; Zone 3, rarely flooded).

\begin{tabular}{cccc}
\hline Location and Season & Zone & $\begin{array}{c}\text { Exchangeable } \\
\mathbf{N O}_{3}-\mathbf{N}(\mathbf{m g} / \mathbf{k g})\end{array}$ & $\begin{array}{c}\text { Exchangeable } \\
\mathbf{N H}_{\mathbf{4}}-\mathbf{N}(\mathbf{m g} / \mathbf{k g})\end{array}$ \\
\hline \multirow{3}{*}{ SIB 1-wet season } & 1 & $0.8(0.4)$ & $2.0(1.2)$ \\
\cline { 2 - 4 } & 2 & $0.8(0.3)$ & $2.1(1.2)$ \\
\cline { 2 - 4 } & 3 & $0.5(0.5)$ & $1.6(0.2)$ \\
\cline { 2 - 4 } SIB 1-dry season & 1 & $0.7(0.0)$ & $7.4(0.4)$ \\
\cline { 2 - 4 } & 2 & $0.7(0.1)$ & $8.1(2.8)$ \\
\hline \multirow{3}{*}{ SIB 2-wet season } & 3 & $0.5(0.0)$ & $7.8(1.2)$ \\
\cline { 2 - 4 } & 1 & $1.1(0.7)$ & $6.3(4.0)$ \\
\hline \multirow{nyyy}{*}{ SIB 2-dry season } & 2 & $0.4(0.1)$ & $10.0(3.7)$ \\
\cline { 2 - 4 } & 3 & $0.5(0.1)$ & $14.7(2.3)$ \\
\cline { 2 - 4 } & 1 & $12.4(11.8)$ & $8.9(0.6)$ \\
\hline
\end{tabular}

\subsection{Inorganic N Production and Denitrification in SIB Soils}

\subsubsection{Net N Mineralization}

There was no significant effect of sediment gradient on net $\mathrm{N}$ mineralization in the SIBs ( $p$-value 0.78). However, there was a significant effect of season on mineralization, with the wet season soils showing significantly higher mineralization than the dry season soils ( $p$-value $<0.001$ ). Net $\mathrm{N}$ mineralization was negligible in SIB 1 during the dry season but increased to an average of 14-15 $\mathrm{mg} \mathrm{N} / \mathrm{kg}$ /day in the wet season, indicating higher rates of $\mathrm{NH}_{4}-\mathrm{N}$ production in the wet season than in the dry season for SIB 1 (Figure 3). In SIB 2, across all sediment zones, there was also more $\mathrm{N}$ mineralization in the wet season, but mineralization rates were much lower for SIB 2 soils than they were for SIB 1 soils (Figure 3). In other human-dominated and natural systems with cycles of wet 
and dry seasons, a number of studies have also shown decreased soil $\mathrm{N}$ mineralization during dry episodes [20,45]. During dry periods, a likely death of microbial biomass leads to reduced turnover of both carbon and $\mathrm{N}$, which reduces $\mathrm{N}$ mineralization rates [46]. Several studies have also shown that the microbial community structure differs in wet versus dry soils, with fungal communities better adapted than bacterial communities to survive dry episodes $[20,47]$. Fungal-dominated systems have been associated with slower $\mathrm{N}$ mineralization rates than bacterial-dominated systems [20]. Thus, a dry season shift in community structure toward more fungal communities may explain reduced mineralization in the dry season, though it is beyond the scope of this paper to investigate the microbial drivers of soil mineralization.

Basin 1

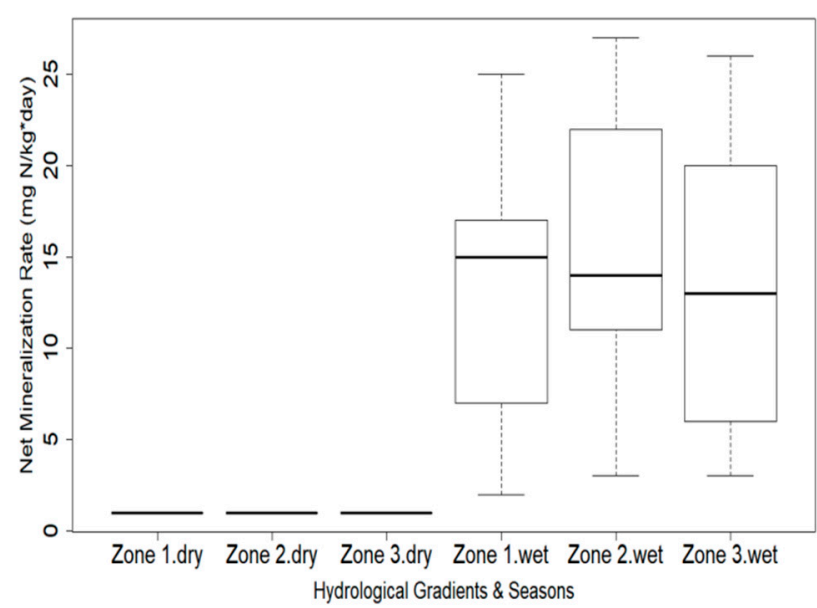

Basin 2

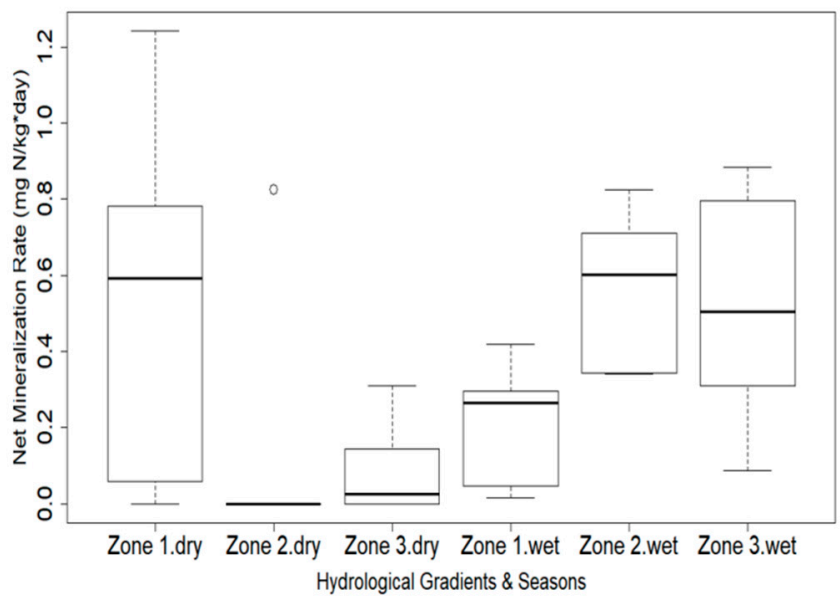

Figure 3. Net $\mathrm{N}$ mineralization rates of SIB soils by zones and seasons. Zone 1, frequently flooded; Zone 2, ocassionally flooded; Zone 3, rarely flooded. Values represent data from the entire soil profile (all three sampling depths).

A significant increase in $\mathrm{N}$ mineralization during the wet season demonstrates that there was a pool of labile $\mathrm{N}$ that may be susceptible to leaching losses at the beginning of the wet season. The increase in net $\mathrm{N}$ mineralization during the wet season was consistent with other studies that have observed that microbial death during the dry season leaves behind a supply of readily degraded organic compounds that can fuel microbial growth when the subsequent wet season stimulates soil microbial growth [48,49]. In this way, the microbial biomass that is killed under dry conditions is readily utilized by microbes upon soil rewetting, and soils undergo increases in both carbon and $\mathrm{N}$ mineralization [46]. This phenomenon of microbes being sustained during wet episodes by organic substrates produced by cell death during dry episodes has led some authors to assert that soils undergoing wet-dry cycling have $\mathrm{N}$ mineralization rates as much as two times those of continuously moist soils [50-52]. This process would presumably lead to losses of $\mathrm{NH}_{4}-\mathrm{N}$ via leaching from the SIBs during wet season flooding events, thus, reducing their $\mathrm{N}$ treatment efficiency unless the increased available $\mathrm{N}$ is utilized by plant roots. As SIBs are designed to undergo periodic wet and dry conditions, the effect of shifts in $\mathrm{N}$ mineralization rates has important implications, namely that future studies should attempt to constrain the mechanisms responsible and investigate SIB design options to increase plant uptake of $\mathrm{NH}_{4}-\mathrm{N}$ during wet episodes.

\subsubsection{Nitrification}

In contrast to net $\mathrm{N}$ mineralization, nitrification rates were highest in the dry season and were negligible during the wet season in both SIBs, with the seasonal difference being significant ( $p$-value $<0.001$ ) (Figure 4 ). While nitrifying bacteria are generally considered to be highly susceptible to water stress, this study is not the only study to observe higher rates of soil nitrification during episodic dry periods $[50,53]$. We propose that nitrifying 
bacteria in the SIBs were able to survive dry episodes and lacked the aerobic environments they needed during wet episodes. Because oxygen in the SIB soil pores would be replaced by water after rain events in the wet season, oxygen-restricted conditions would exert temporary negative impacts on the abundance and activity of nitrifying bacteria. High nitrification rates coupled with low potential denitrification (as discussed below) are important for SIB treatment efficiency and $\mathrm{N}$ leaching and enrichment of groundwater. Davis et al. [54] showed that $\mathrm{NO}_{\mathrm{x}}$ anions created by the nitrification process had low sorption to soils and high mobility to groundwater in Florida sandy soils. Thus, the high $\mathrm{NO}_{3}{ }^{-}$production in SIB soils during the dry season would result in the risk of degradation of groundwater quality during sporadic rain events in the dry season, which account for $30-35 \%$ of annual precipitation in Florida.
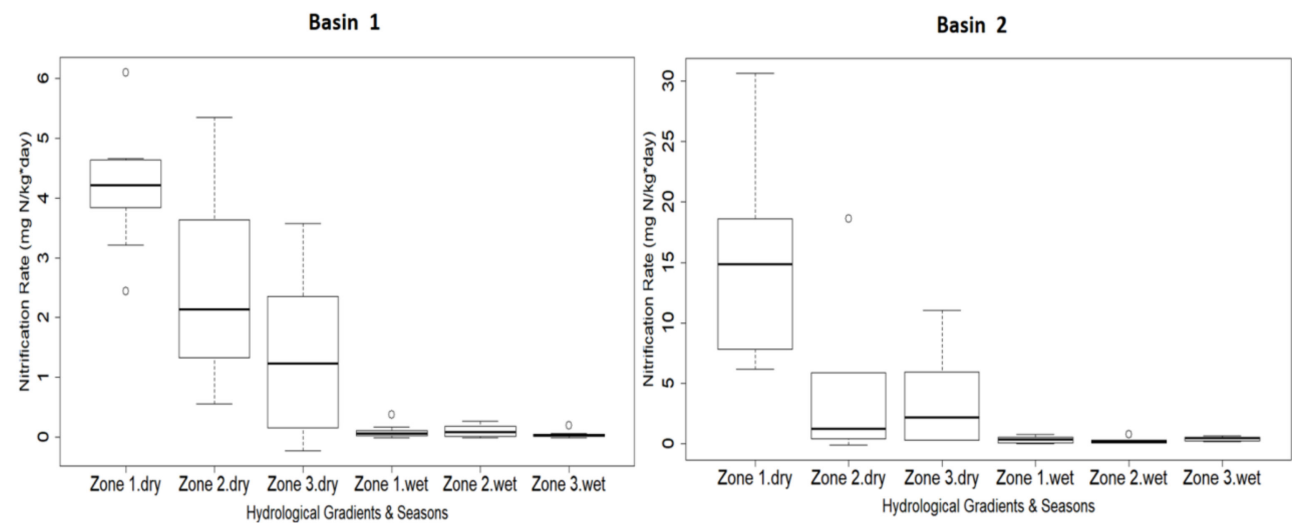

Figure 4. Nitrification rates of SIB soils by zones and seasons. Zone 1, frequently flooded; Zone 2, ocassionally flooded; Zone 3, rarely flooded. Values represent data from the entire soil profile (all three sampling depths).

Nitrification rates significantly decreased along the sediment gradient in both SIBs ( $p$-value $<0.001$ ), indicating that nitrate production in each SIB is expected to have a strong spatial trend that increases as does the spatial frequency of flooding in the SIBs. While our study does not investigate the causal mechanisms of this trend, we did observe that nitrification rates were significantly positively related to soil $\mathrm{pH}$ ( $p$-value 0.01 ), soil total $\mathrm{N}$ ( $p$-value 0.001$)$, and soil total $\mathrm{C}(p$-value 0.01$)$. The optimum $\mathrm{pH}$ for nitrification in soils is around 8.5 [55], with nitrification generally decreasing with soil $\mathrm{pH}$ values below 8.5 (Table 2). In this study, SIB soils had $\mathrm{pH}$ values closer to this optimum value near the inflows (Zone 1) where flooding and sediment accumulation was more frequent and nitrification was higher. Higher concentrations of inorganic $C$ (carbonates, as buffering material, Table 1) accumulated at the inflow of SIBs may be the reason for higher $\mathrm{pH}$ values in Zone 1. Sources of material that induce high alkalinity in this zone could include concrete and other construction materials in the neighborhood streets and stormwater conveyance pipes [56,57]. Further study should be done to better identify the mechanisms that drive nitrification rate trends in SIBs. If a $\mathrm{pH}$ difference is indeed one of these driving mechanisms, as suggested by this study, then use of concrete gutters to convey stormwater should be reconsidered, as it may have $\mathrm{pH}$ effects that drive increased $\mathrm{NO}_{3}{ }^{-}$production in SIB soils.

Both net mineralization and nitrification rates decreased with soil depth (Supplementary Materials Table S1), which was related to the concomitant decreases in organic matter and moisture content, showing that the carbon- and nutrient-rich and moist topsoil provided a favorable environment for microbial survival and activity.

\subsubsection{Denitrification}

As one process that can permanently remove $\mathrm{N}$ from the soil, denitrification is a key factor in this study to identify the $\mathrm{N}$ removal efficiency in SIBs. Denitrification rates were 
generally higher in the inlet surface layer $(0-30 \mathrm{~cm})$ of the SIBs and decreased along the depth gradient, indicating that higher inorganic $\mathrm{N}$ removal would be expected closer to the SIB topsoils and inlet zones (Figure 5 and Supplemental Table S1). Likewise, denitrification generally decreased along the sediment gradient from Zone 1 to Zone 3, indicating that higher inorganic $\mathrm{N}$ removal would be expected closer to the SIB inlet zones (Figure 5). It is likely that sediment-enriched soils around the inlet pipes may be hotspots of $\mathrm{N}$ removal. This is likely because sediments accumulating around the inflow areas are more likely to stay inundated and drive stable soil moisture during dry-rewetting conditions, which in turn promotes the anaerobic soil conditions necessary for denitrification [26]. The sediments from inflowing stormwater also supply organic $C$, which is also necessary for denitrification $[10,58]$.

Basin 1

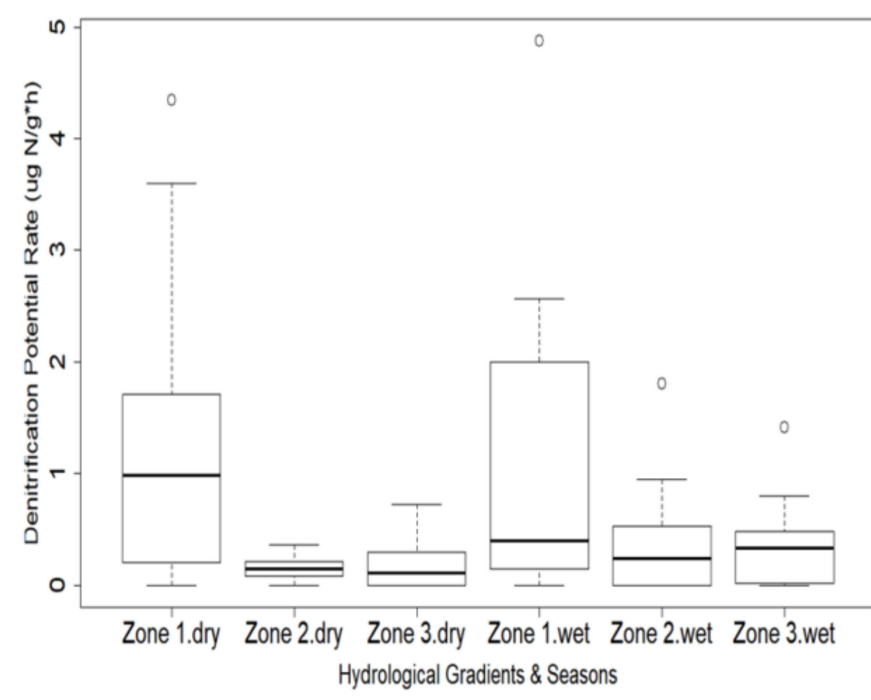

Basin 2

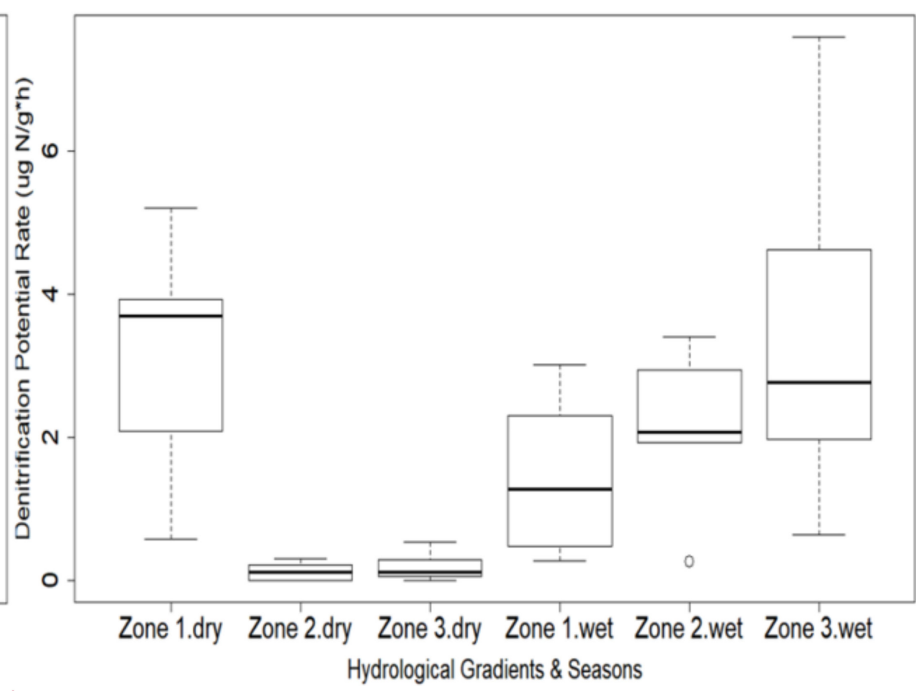

Figure 5. Potential dentrification rates in SIB soils by zones and seasons. Zone 1, frequently flooded; Zone 2, occasionally flooded; Zone 3, rarely flooded. Values represent data from the entire soil profile (all three sampling depths).

Although we expected to see significant denitrification potential differences between wet and dry seasons, the increase of the overall potential denitrification rate from dry to wet season was not significant. We expected to measure much higher DEA in the wet season than in dry season due to an increased anaerobic condition from soil inundation. The possible explanation of our unexpected results might be the adaption of the microbial community to fluctuating soil moisture conditions. For example, unlike ponds and retention basins that are built to hold water in urban systems, frequent drought condition in SIBs can induce physiological adaptation of denitrifers, and thus flatten their metabolic responses [59], accounting for the insignificant seasonal denitrification potential change in this system. Future studies should investigate the microbial mechanisms and drivers of our observation that denitrification did not vary between wet and dry season.

\section{Implications for Stormwater Control Measure Efficiency}

Identifying the spatiotemporal differences of $\mathrm{N}$ production and removal capability of SIBs can be essential for improving the role of SIBs in pollutant control, as well as providing a reference for future urban SCM construction and designs. Each season of our study had a characteristic inorganic $\mathrm{N}$ form in SIB soils, i.e., $\mathrm{NH}_{4}{ }^{+}$during the wet season and $\mathrm{NO}_{3}{ }^{-}$during the dry season. As a highly mobile form of $\mathrm{N}, \mathrm{NO}_{3}{ }^{-}$produced during the dry season would be likely to leach during periodic dry season storms or after the onset of the wet season, potentially reducing the $\mathrm{N}$ treatment efficiency of our SIBs as a stormwater BMP. Our study also demonstrated a spatial trend of inorganic N removal via denitrification, reaching its highest value near SIB inflow pipes where frequent 
flooding and organic sediment accumulation likely create a denitrification hotspot. In order to accomplish the goal of improving urban water quality, the primary purpose of constructing BMP infrastructure is to reduce the transport of excess nutrients and pollutants into groundwater. This is a preliminary study, but it helps to understand and predict the influence of a hydrological sediment gradient and seasonal variation during the production and removal of inorganic $\mathrm{N}$ by urban SIBs. To mitigate the pollution threat of excess $\mathrm{N}$ to water bodies in urban areas, future research should address soil drivers of $\mathrm{N}$ cycling in SIBs, with particular emphasis on important factors suggested here, namely potential effects of microbial community composition on inorganic $\mathrm{N}$ production, potential effects of high $\mathrm{pH}$ on increasing nitrate production, and spatial gradients in denitrification that may arise due to differences in flooding and organic sediment accumulation in SIBs.

Supplementary Materials: The following are available online at https: / /www.mdpi.com/2073-4 441/13/3/320/s1, Supplementary Table S1. Average Rates of N-cycling Activities and Extractable Inorganic $\mathrm{N}( \pm \mathrm{SE})$ in Different Seasons and Hydrological Zones.

Author Contributions: Conceptualization, Q.S., M.G.L. and P.W.I.; methodology, Q.S., M.G.L., and P.W.I.; formal analysis, Q.S.; investigation, Q.S. and M.G.L.; resources, M.G.L and P.W.I.; writingoriginal draft preparation, Q.S. and M.G.L.; writing—review and editing, M.G.L. and P.W.I.; funding acquisition, M.G.L. All authors have read and agreed to the published version of the manuscript.

Funding: This research was funded in part by the Center for Land Use Efficiency.

Informed Consent Statement: Not applicable.

Data Availability Statement: The data presented in this study are available in the article and the supplementary material.

Acknowledgments: We gratefully acknowledge the assistance of Kylie Chapman in field sampling and sample processing, and Sophia Barbour of the Wetland Biogeochemistry Laboratory for assistance in sample analysis.

Conflicts of Interest: The authors declare no conflict of interest.

\section{References}

1. Lee, J.; Bang, K.; Ketchum, L.; Choe, J.; Yu, M. First flush analysis of urban storm runoff. Sci. Total Environ. 2002, 293, 163-175. [CrossRef]

2. Walsh, C.J.; Roy, A.H.; Feminella, J.W.; Cottingham, P.D.; Groffman, P.M.; Morgan, R.P., II. The urban stream syndrome: Current knowledge and the search for a cure. J. N. Am. Benthol. Soc. 2005, 24, 706-723. [CrossRef]

3. Yang, Y.-Y.; Lusk, M.G. Nutrients in Urban Stormwater Runoff: Current State of the Science and Potential Mitigation Options. Curr. Pollut. Rep. 2018, 4, 112-127. [CrossRef]

4. Conley, D.J.; Paerl, H.W.; Howarth, R.W.; Boesch, D.F.; Seitzinger, S.P.; Havens, K.E.; Lancelot, C.; Likens, G.E. Controlling Eutrophication: Nitrogen and Phosphorus; American Association for the Advancement of Science: Washington, DC, USA, 2009.

5. Howarth, R.; Paerl, H.W. Coastal marine eutrophication: Control of both nitrogen and phosphorus is necessary. Proc. Natl. Acad. Sci. USA 2008, 105, E103. [CrossRef] [PubMed]

6. Albertin, A.R.; Sickman, J.O.; Pinowska, A.; Stevenson, R.J. Identification of nitrogen sources and transformations within karst springs using isotope tracers of nitrogen. Biogeochemistry 2012, 108, 219-232. [CrossRef]

7. Xing, J.; Song, J.; Yuan, H.; Li, X.; Li, N.; Duan, L.; Kang, X.; Wang, Q. Fluxes, seasonal patterns and sources of various nutrient species (nitrogen, phosphorus and silicon) in atmospheric wet deposition and their ecological effects on Jiaozhou Bay, North China. Sci. Total Environ. 2017, 576, 617-627. [CrossRef]

8. Krimsky, L.S.; Lusk, M.G.; Abeels, H.; Seals, L. Sources and concentrations of nutrients in surface runoff from waterfront homes with different landscape practices. Sci. Total Environ. 2020, 750, 142320. [CrossRef]

9. Kaushal, S.S.; Groffman, P.M.; Band, L.E.; Elliott, E.M.; Shields, C.A.; Kendall, C. Tracking nonpoint source nitrogen pollution in human-impacted watersheds. Envirom. Sci. Technol. 2011, 45, 8225-8232. [CrossRef]

10. Lusk, M.G.; Toor, G.S.; Inglett, P.W. Organic nitrogen in residential stormwater runoff: Implications for stormwater management in urban watersheds. Sci. Total Environ. 2020, 707, 135962. [CrossRef]

11. Yang, Y.-Y.; Toor, G.S. Sources and mechanisms of nitrate and orthophosphate transport in urban stormwater runoff from residential catchments. Water Res. 2017, 112, 176-184. [CrossRef]

12. Collins, K.; Lawrence, T.; Stander, E.; Jontos, R.; Kaushal, S.; Newcomer, T.; Grimm, N.; Ekberg, M. Opportunities and challenges for managing nitrogen in urban stormwater: A review and synthesis. Ecol. Eng. 2010, 36, 1507-1519. [CrossRef] 
13. Koch, B.J.; Febria, C.M.; Gevrey, M.; Wainger, L.A. Nitrogen removal by stormwater management structures: A data synthesis. J. Am. Water Resour. Assoc. 2014, 50, 1594-1607. [CrossRef]

14. Peluso, V.; Marshall, A. Best Management Practices for South Florida Urban Stormwater Management Systems; Technical Publication REG-044; South Florida Water Management District, Everglades Stormwater Program: West Palm Beach, FL, USA, 2002.

15. Clary, J.; Jones, J.; Leisenring, M.; Hobson, P.; Strecker, E. International Stormwater BMP Database: 2016 Summary Statistics; The Water Environment \& Reuse Foundation: Alexandria, VA, USA, 2017.

16. Badin, A.L.; Monier, A.; Volatier, L.; Geremia, R.A.; Delolme, C.; Bedell, J.-P. Structural stability, microbial biomass and community composition of sediments affected by the hydric dynamics of an urban stormwater infiltration basin. Microb. Ecol. 2011, 61, 885-897. [CrossRef] [PubMed]

17. Fang, H.; Zhou, H.; Norton, G.J.; Price, A.H.; Raffan, A.C.; Mooney, S.J.; Peng, X.; Hallett, P.D. Interaction between contrasting rice genotypes and soil physical conditions induced by hydraulic stresses typical of alternate wetting and drying irrigation of soil. Plant. Soil 2018, 430, 233-243. [CrossRef] [PubMed]

18. Mikha, M.M.; Rice, C.W.; Milliken, G.A. Carbon and nitrogen mineralization as affected by drying and wetting cycles. Soil Biol. Biochem. 2005, 37, 339-347. [CrossRef]

19. Hammerl, V.B.; Grant, K.; Pritsch, K.; Jentsch, A.; Schloter, M.; Beierkuhnlein, C.; Gschwendtner, S. Seasonal effects of extreme weather events on Potential Extracellular Enzyme Activities in a temperate grassland soil. Front. Environ. Sci. 2019, 6, 157. [CrossRef]

20. Austin, A.T.; Yahdjian, L.; Stark, J.M.; Belnap, J.; Porporato, A.; Norton, U.; Ravetta, D.A.; Schaeffer, S.M. Water pulses and biogeochemical cycles in arid and semiarid ecosystems. Oecologia 2004, 141, 221-235. [CrossRef]

21. Franzluebbers, A.; Haney, R.; Honeycutt, C.; Schomberg, H.-H.; Hons, F. Flush of carbon dioxide following rewetting of dried soil relates to active organic pools. Soil Sci. Soc. Am. J. 2000, 64, 613-623. [CrossRef]

22. Barber, S.A. Soil Nutrient Bioavailability: A Mechanistic Approach; John Wiley \& Sons: Hoboken, NJ, USA, 1995.

23. Vilain, G.; Garnier, J.; Tallec, G.; Tournebize, J. Indirect $\mathrm{N}_{2} \mathrm{O}$ emissions from shallow groundwater in an agricultural catchment (Seine Basin, France). Biogeochemistry 2012, 111, 253-271. [CrossRef]

24. Gillam, K.; Zebarth, B.; Burton, D. Nitrous oxide emissions from denitrification and the partitioning of gaseous losses as affected by nitrate and carbon addition and soil aeration. Can. J. Soil Sci. 2008, 88, 133-143. [CrossRef]

25. Wang, X.; Zhao, X.; Peng, C.; Zhang, X.; Wang, J. A field study to evaluate the impact of different factors on the nutrient pollutant concentrations in green roof runoff. Water Sci. Technol. 2013, 68, 2691-2697. [CrossRef] [PubMed]

26. Bettez, N.D.; Groffman, P.M. Denitrification Potential in Stormwater Control Structures and Natural Riparian Zones in an Urban Landscape. Environ. Sci. Technol. 2012, 46, 10909-10917. [CrossRef]

27. Morse, N.R.; McPhillips, L.E.; Shapleigh, J.P.; Walter, M.T. The Role of Denitrification in Stormwater Detention Basin Treatment of Nitrogen. Environ. Sci. Technol. 2017, 51, 7928-7935. [CrossRef] [PubMed]

28. McPhillips, L.; Walter, M.T. Hydrologic conditions drive denitrification and greenhouse gas emissions in stormwater detention basins. Ecol. Eng. 2015, 85, 67-75. [CrossRef]

29. O'Reilly, A.M.; Wanielista, M.P.; Chang, N.-B.; Xuan, Z.; Harris, W.G. Nutrient removal using biosorption activated media: Preliminary biogeochemical assessment of an innovative stormwater infiltration basin. Sci. Total Environ. 2012, 432, $227-242$. [CrossRef] [PubMed]

30. Rosenzweig, B.R.; Groffman, P.M.; Zarnoch, C.B.; Branco, B.F.; Hartig, E.K.; Fitzpatrick, J.; Forgione, H.M.; Parris, A. Nitrogen regulation by natural systems in "unnatural" landscapes: Denitrification in ultra-urban coastal ecosystems. Ecosyst. Health Sustain. 2018, 4, 205-224. [CrossRef]

31. Ishida, C.K.; Kelly, J.J.; Gray, K.A. Effects of variable hydroperiods and water level fluctuations on denitrification capacity, nitrate removal, and benthic-microbial community structure in constructed wetlands. Ecol. Eng. 2006, 28, 363-373. [CrossRef]

32. Palmer, K.; Köpp, J.; Gebauer, G.; Horn, M.A. Drying-rewetting and flooding impact denitrifier activity rather than community structure in a moderately acidic fen. Front. Microbiol. 2016, 7, 727. [CrossRef]

33. Cannavo, P.; Vidal-Beaudet, L.; Béchet, B.; Lassabatère, L.; Charpentier, S. Spatial distribution of sediments and transfer properties in soils in a stormwater infiltration basin. J. Soils Sediments 2010, 10, 1499-1509. [CrossRef]

34. Morse, J.L.; Ardón, M.; Bernhardt, E.S. Using environmental variables and soil processes to forecast denitrification potential and nitrous oxide fluxes in coastal plain wetlands across different land uses. J. Geophys. Res. Biogeosci. 2012, 117. [CrossRef]

35. Lusk, M.G.; Toor, G.S. Optimizing the hydrologic properties of urban soils. In Urban Soils; CRC Press: Boca Raton, FL, USA, 2018.

36. Datry, T.; Malard, F.; Vitry, L.; Hervant, F.; Gibert, J. Solute dynamics in the bed sediments of a stormwater infiltration basin. J. Hydrol. 2003, 273, 217-233. [CrossRef]

37. Lassabatere, L.; Angulo-Jaramillo, R.; Goutaland, D.; Letellier, L.; Gaudet, J.; Winiarski, T.; Delolme, C. Effect of the settlement of sediments on water infiltration in two urban infiltration basins. Geoderma 2010, 156, 316-325. [CrossRef]

38. Havlin, J.; Kissel, D.; Maddux, L.; Claassen, M.; Long, J. Crop rotation and tillage effects on soil organic carbon and nitrogen. Soil Sci. Soc. Am. J. 1990, 54, 448-452. [CrossRef]

39. Murphy, B. Impact of soil organic matter on soil properties-A review with emphasis on Australian soils. Soil Res. 2015, 53, 605-635. [CrossRef]

40. USDA, Web Soil Survey. Natural Resources Conservation Service, US Department of Agriculture: Undated. Available online: https:/ / websoilsurvey.sc.egov.usda.gov / App/HomePage.htm (accessed on 27 January 2019). 
41. Harris, D.; Horwáth, W.R.; Van Kessel, C. Acid fumigation of soils to remove carbonates prior to total organic carbon or carbon-13 isotopic analysis. Soil Sci. Soc. Am. J. 2001, 65, 1853-1856. [CrossRef]

42. Groffman, P.M.; Crawford, M.K. Denitrification potential in urban riparian zones. J. Environ. Qual. 2003, 32, 1144-1149. [CrossRef]

43. Liao, X.; Inglett, P.W.; Inglett, K.S. Seasonal patterns of nitrogen cycling in subtropical short-hydroperiod wetlands: Effects of precipitation and restoration. Sci. Total Environ. 2016, 556, 136-145. [CrossRef]

44. Kaushal, S.S.; Duan, S.; Doody, T.R.; Haq, S.; Smith, R.M.; Johnson, T.A.N.; Newcomb, K.D.; Gorman, J.; Bowman, N.; Mayer, P.M. Human-accelerated weathering increases salinization, major ions, and alkalinization in fresh water across land use. Appl. Geochem. 2017, 83, 121-135. [CrossRef]

45. Mummey, D.; Smith, J.; Bolton, H., Jr. Nitrous oxide flux from a shrub-steppe ecosystem: Sources and regulation. Soil Biol. Biochem. 1994, 26, 279-286. [CrossRef]

46. Bottner, P. Response of microbial biomass to alternate moist and dry conditions in a soil incubated with $14 \mathrm{C}$-and $15 \mathrm{~N}-\mathrm{labelled}$ plant material. Soil Biol. Biochem. 1985, 17, 329-337. [CrossRef]

47. Wilson, J.M.; Griffin, D. Water potential and the respiration of microorganisms in the soil. Soil Biol. Biochem. 1975, 7, 199-204. [CrossRef]

48. Halverson, L.J.; Jones, T.M.; Firestone, M.K. Release of intracellular solutes by four soil bacteria exposed to dilution stress. Soil Sci. Soc. Am. J. 2000, 64, 1630-1637. [CrossRef]

49. Van Gestel, M.; Merckx, R.; Vlassak, K. Soil drying and rewetting and the turnover of 14C-labelled plant residues: First order decay rates of biomass and non-biomass 14C. Soil Biol. Biochem. 1993, 25, 125-134. [CrossRef]

50. Cabrera, M. Modeling the flush of nitrogen mineralization caused by drying and rewetting soils. Soil Sci. Soc. Am. J. 1993, 57, 63-66. [CrossRef]

51. Iovieno, P.; Bååth, E. Effect of drying and rewetting on bacterial growth rates in soil. FEMS Microbiol. Ecol. 2008, 65, 400-407. [CrossRef]

52. Miller, A.E.; Schimel, J.P.; Meixner, T.; Sickman, J.O.; Melack, J.M. Episodic rewetting enhances carbon and nitrogen release from chaparral soils. Soil Biol. Biochem. 2005, 37, 2195-2204. [CrossRef]

53. Fierer, N.; Schimel, J.P. Effects of drying-rewetting frequency on soil carbon and nitrogen transformations. Soil Biol. Biochem. 2002, 34, 777-787. [CrossRef]

54. Davis, A.P.; Shokouhian, M.; Sharma, H.; Minami, C. Water quality improvement through bioretention media: Nitrogen and phosphorus removal. Water Environ. Res. 2006, 78, 284-293. [CrossRef]

55. Sahrawat, K. Factors affecting nitrification in soils. Commun. Soil Sci. Plant Anal. 2008, 39, 1436-1446. [CrossRef]

56. Vadas, T.M.; Smith, M.; Luan, H. Leaching and retention of dissolved metals in particulate loaded pervious concrete columns. J. Environ. Manag. 2017, 190, 1-8. [CrossRef]

57. Grella, C.; Wright, I.A.; Findlay, S.J.; Jonasson, O.J. Geochemical contamination of urban water by concrete stormwater infrastructure: Applying an epoxy resin coating as a control treatment. Urban Water J. 2016, 13, 212-219. [CrossRef]

58. Jani, J.; Toor, G.S. Composition, sources, and bioavailability of nitrogen in a longitudinal gradient from freshwater to estuarine waters. Water Res. 2018, 137, 344-354. [CrossRef] [PubMed]

59. Reverey, F.; Grossart, H.-P.; Premke, K.; Lischeid, G. Carbon and nutrient cycling in kettle hole sediments depending on hydrological dynamics: A review. Hydrobiologia 2016, 775, 1-20. [CrossRef] 